\title{
3 Strategic responsible innovation management (StRIM)
}

\author{
A new approach to responsible \\ corporate innovation through \\ strategic CSR
}

Agata Gurzawska

\subsection{Introduction}

Over recent decades, companies have operated in complex business environments. On the one hand companies are facing fierce competition and need to achieve and manage innovation to maintain a competitive advantage and improve their financial performance and market share. On the other hand, businesses need to fulfil their legal obligations and seek to improve their corporate social responsibility (CSR) for multiple stakeholders in order to gain greater social acceptance of their activities. Despite the popularity of both innovation management and CSR most companies do not necessarily connect them and manage them strategically (Husted and Allen 2007; Husted, Allen et al. 2015). We lack a broader holistic perspective on the complex connection between innovation and CSR (McWilliams and Siegel 2006; Yin and Jamali 2016). In other words, we do not have a strategic and generic business model connecting innovation and CSR, through which innovation practices can create business value and positive societal and environmental change. The disconnectedness of these two aspects of corporate activities may lead to missed business opportunities, avoidable financial losses for a company in the long run, as well as negative economic, societal and environmental impacts. Therefore, the challenge is to innovate in a responsible way. An effective strategic approach to responsible corporate innovation would have sustainable outcomes for both business and society. I argue that intertwining innovation and CSR may bring opportunities for both business and society. In order to bring sustainable economic, societal and environmental outcomes, companies should have a strategic approach to innovation and CSR management. This chapter places the assessment of responsible innovation (including measuring, monitoring and reporting) in a broader picture of a business strategy. This analysis is crucial to understand why, when and how the evaluation and control of responsible innovation should be done in order to mitigate risks and strengthen strategic planning. 


\section{Agata Gurzawska}

The remainder of this study is as follows: Section 3.2 defines the concepts of innovation and CSR, explores their relation to business strategy and addresses current discussions providing the theoretical understanding based on the existing literature; Section 3.3 explores the connection between innovation and CSR with a reference to the concepts of Responsible Research and Innovation (RRI), CSR-driven innovation, innovation-driven CSR and the multi-stakeholder approach; Section 3.4 derives from the strategic management literature and formulates a new approach called strategic responsible innovation management (StRIM); and Section 3.5 summarizes the findings.

\subsection{Innovation, CSR and their relation to business strategy}

\subsubsection{Innovation}

Innovation in the business context can be broadly defined as the successful application of new ideas (Dodgson, Gann et al. 2013). Various definitions of innovation exist; however this study takes a holistic approach to innovation, characterised as 'the implementation of a new or significantly improved product (good or service), or process, a new marketing method, or a new organisational method in business practices, workplace organisation or external relations' (OECD 2005). Therefore, four types of innovation can be differentiated that encompass a wide range of changes in companies' activities: product innovations, process innovations, organisational innovations and marketing innovations (OECD 2005). The crucial characteristic of innovation is that it is not a single action, a single idea or the invention of a single new device, but rather an integrated process involving various steps (Trott 2008; Conway and Steward 2009). Innovation emerges from various sources and has a multiplicity of influences, e.g. new regulations, new technological standard, collaborative partners or potential funding opportunity (Dodgson, Gann et al. 2013). However, there are two main sources of innovation, namely market pull and technology push (Bennett and Cooper 1981). Innovation originating from market pull comes from consumers' needs and identifying new market opportunities or a segment of an existing market that has been neglected (Whittington 2001; Baker 2014), whereas technology push comes from scientists and engineers, thereby scientific discovery or the availability of new technology leads to the development of a product (Bennett and Cooper 1981). Innovation is a crucial competence because it enables a company to adapt to the dynamically changing needs of the marketplace and is pivotal to the profitability and long-term survival of any company (Hauser, Tellis et al. 2006).

As far as innovation is said to be a key driver of economic development (Hanekamp 2007), it may challenge ethical values and human rights. One of Kranzberg's laws states that 'technology is neither good nor bad; nor is it neutral' (Kranzberg 1986). Recent controversies around misuse of Facebook users' data by Cambridge Analytica and potential implications for the US 
presidential elections in 2016 or the Social Credit System introduced in China (to score its citizens based on various data, including social media information) (Reuters 2018) raise legitimate concerns as to whether innovation, science and technology can be left to operate autonomously in the market without societal guidance and regulation. These considerations raise questions about companies' responsibilities for their innovation activities with respect to the environment, stakeholders and society. This issue is often discussed in relation to the more widely known concept of CSR.

\subsubsection{Corporate social responsibility}

The debate on whether companies have responsibilities to society beyond making profits has created an enormous amount of interest and controversy over the last 60 years. Nevertheless, companies more often recognise that they do have responsibilities that go beyond immediate shareholders and making profits (Crane and Matten 2016). Companies operate in, and interact with, society and the environment and serve customers in one or more countries. They fulfil their responsibilities by applying the wellestablished concept of CSR, which is a popular business management concept. Many companies have put some sort of CSR policy in place or have made explicit CSR communications (Maignan and Ralston 2002).

The most well-known definition of corporate responsibilities is Carroll's (1979, 1991) definition of CSR which identifies four categories of responsibilities: economic, legal, ethical and discretionary/philanthropic (Carroll 1979, 1991). Dahlsrud (2008), in a comprehensive review of CSR definitions, identifies five dimensions of CSR, specifically, environmental, social, economic, stakeholder and voluntariness. Garriga and Melé (2004) suggest there are four groups of CSR theories, namely instrumental, political, integrative and ethical theories. Basu and Palazzo (2008) propose that business approaches to study of CSR can be divided into three categories: (1) stakeholder-driven (pressures from external stakeholders); (2) performance-driven (the effectiveness of CSR actions in terms of their purpose by the organisation and their impact on the outside world); and (3) motivation-driven (the reasons why organisations undertake CSR) (Basu and Palazzo 2008). From the managerial perspective, CSR can be defined as:

the process by which managers within an organisation think about and discuss their relationship with stakeholders as well as their roles in relation to the common good, along with the behavioural dispositions with respect to the fulfilment and achievement of those roles and relationships.

(Basu and Palazzo 2008)

There are many ways to think about CSR, but broadly speaking, CSR refers to responsibility, hence duties and obligations or motivation and opportunities of the companies towards society (Gurzawska et al. 2015). 
CSR derives from organisational sensemaking and dwells as an intrinsic part of a company's character (Basu and Palazzo 2008).

\subsubsection{Strategy and strategic management}

In today's complex business world, corporate success depends on crafting and implementing effective business strategies (De Kluyver and Pearce 2006). According to Mintzberg's and McHugh's 'grass-roots model' (1985), a strategy consists of intended and focused plans, on the one hand, and of emergent and often highly unexpected developments, on the other hand (Mintzberg and McHugh 1985). Rapid changes in the competitive environment require 'crafting long-term vision for an organisation while maintaining a degree of flexibility about how to get there and creating a portfolio of options for adapting to change' (De Kluyver and Pearce 2006). Therefore, strategic management can be defined as the field dealing with 'the major intended and emergent initiatives taken by general managers on behalf of owners, involving utilisation of resources, to enhance the performance of companies in their external environments' (Nag, Hambrick et al. 2007). Husted and Allen (2000) incorporate these definitions, and construe strategy as plans and actions taken to create unique resources and capabilities that leverage organisational routines and that are the source of sustainable competitive advantage and superior performance. From a practice point of view, strategy is about creating tools for managers to decide about how the company is going to win in the future (Husted and Allen 2010).

The purpose of strategic management is to bring about the conditions under which the organisation is able to create value. Value can be created through either the development of new products, processes, organisational innovations and marketing innovations or through the creation of entirely new markets (Husted and Allen 2007). In other words, companies use strategies to provide a competitive advantage or avoid a competitive disadvantage (Powell 2001). Husted and Allen (2010) argue that corporate strategy aims to achieve superior performance and both economic and social objectives of the company (gain economic and social competitive advantage or avoid economic or social disadvantage) (Husted and Allen 2010). They perceive strategy as a rational process that seeks two valuable and rational ends economic value creation and social value creation (Husted and Allen 2010).

\subsubsection{Innovation and strategy}

There is a deep connection between corporate and innovation strategy in many business sectors (Berkhout 2013). Innovation is regarded as the focal point of a company's strategy (Milling and Stumpfe 2000). Innovation influences various aspects of companies' economic performance and corporate competitiveness, ranging from effects on sales and market share to changes in productivity and efficiency (OECD 2005). Nevertheless, benefits 
from innovation vastly depend upon how well it is managed. Therefore, in recent years, the field of managing and shaping innovation has attracted considerable attention from academics, policy makers and business practitioners (Conway and Steward 2009). The definition of innovation implies a process that involves the elements of strategic management, and therefore it should also reflect this systemic, strategic approach to innovation. According to this approach, the company is a system of interrelated and interdependent parts (White and Bruton 2010) that involves a framework of inputs, transformations, outputs (Muller, Välikangas et al. 2005; De Weerd-Nederhof 2007; Davila, Epstein et al. 2012) and feedback along the entire process (White and Bruton 2010). Figure 3.1 presents the system approach to innovation management.

Innovation is managed strategically through creating supportive structures, practices and processes which additionally requires that companies are in harmony with the contextual conditions in which they operate (Dodgson, Gann et al. 2013). Innovation is an organisation-wide concern that affects all units in a company, its organisational structure, people, processes, procedures and systems (White and Bruton 2010). Many

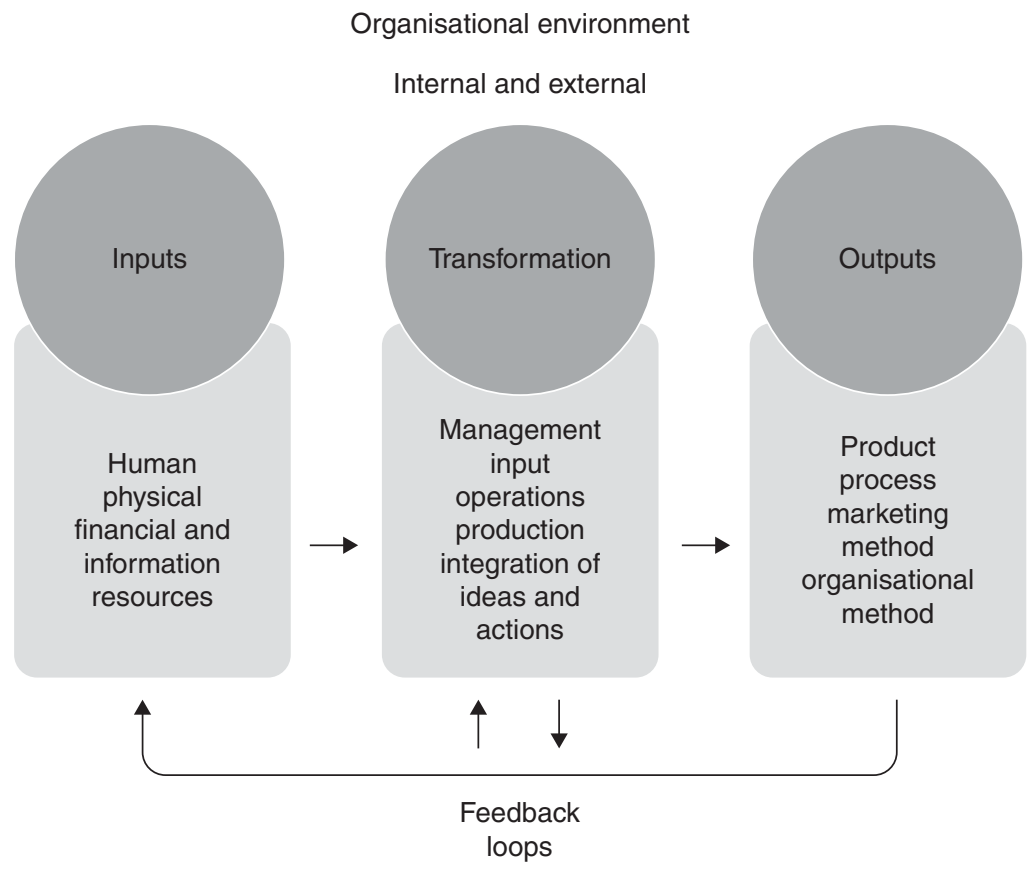

Figure 3.1 A system approach to innovation management. (Adapted from De WeerdNederhof; White and Bruton, 2010; and Davila et al. 2012; Muller et al. 2005.) 
businesses that engage in innovation have separate research and development (R\&D) divisions, innovation managers or innovation boards, which are often a driving force for their success.

\subsubsection{CSR and strategy}

Over recent decades CSR has shifted from the margins to the mainstream of business practice. The concept and scope of CSR have also evolved, from mere philanthropic action to so-called strategic CSR (Baron 2001; Lantos 2001; Gugler and Shi 2009), where corporate responsibility is managed in a systematic and intentional way. As emphasised by Galbreath (2006), 'CSR is ultimately a strategic issue, one that cannot be separated from a firm's overall strategy' (Galbreath 2006). According to the strategic CSR literature, CSR is strategic when it is integrated into companies' core business operation and, therefore, as an important part of corporate competitive strategy as it yields substantial business-related benefits to the company (Burke and Logsdon 1996). In other words strategic CSR is:

a business strategy that is integrated with core business objective and core competencies of the company, and from the outside is designed to create business value and positive social change, and is embedded in a day-to-day business culture and operations.

(McElhaney 2009)

Strategic CSR engagement is at the heart of the core business model and is brought into central value creation (Midttun 2009).

Many companies choose a CSR agenda and engage in 'doing good' by developing and engaging in projects that meet societal and environmental obligations and objectives, irrespective of a company's interest (Husted, Allen et al. 2015). Porter and Kramer (2006) assert that businesses usually only consider CSR in generic ways instead of in ways appropriate for their future strategies. In contrast to simply 'doing good', a strategic approach to CSR requires that companies deliberately create, implement and measure strategic investment and outcomes of social projects that seek a competitive advantage and economic value (Porter 1985; Liedtka 2000). In this way social projects replicate the strategic intention of 'market' behaviour (Husted, Allen et al. 2015). CSR needs to be considered more in terms of the opportunities it provides to the business and a fundamental value creation driver, rather that a reactive-defensive strategy and a support function to reduce risks and costs for shareholders (Midttun 2009; von Weltzien Høivik and Shankar 2011). Lantos (2001) differentiates strategic CSR from ethical CSR (moral responsibility to any individuals or groups where a company might inflict actual or potential injury) and altruistic CSR (being a 'good corporate citizen' by 'giving back' to society, regardless of whether or not this will benefit the company itself). He emphasises that strategic CSR 


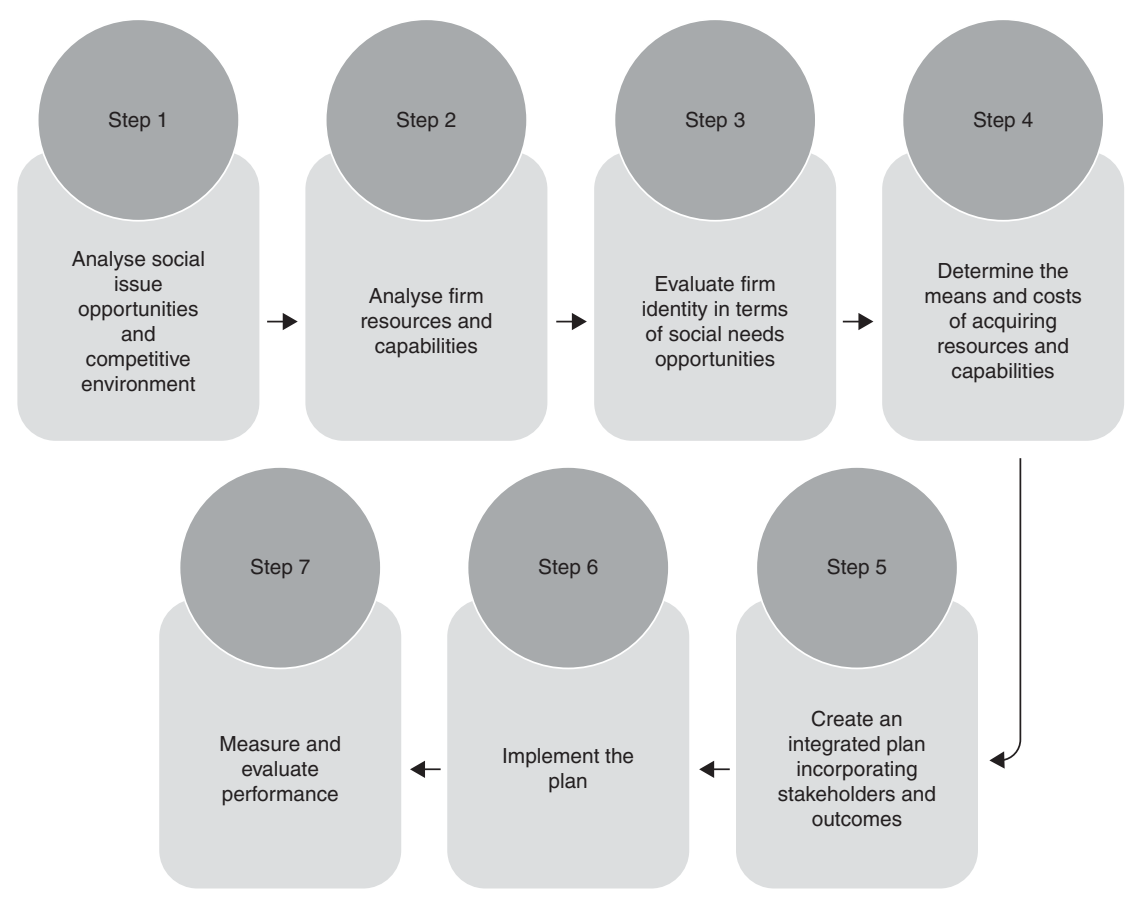

Figure 3.2 Seven-step model of corporate social strategy. (Adapted from Husted and Allen 2010.)

'creates a win-win situation in which both the company and one or more stakeholder groups benefit' (Lantos 2001). Husted and Allen (2010) propose a seven-step model of corporate social strategy (Figure 3.2) based in strategic analysis literature (Husted and Allen 2010).

Some scholars look into CSR from the 'business case' perspective and claim that strategic CSR can improve corporate competitiveness and, subsequently companies' economic and financial performance (Burke and Logsdon 1996; Zadek 2000; Kurucz, Colbert et al. 2008; Carroll and Shabana 2010). Porter and Kramer, the pioneers of connecting CSR and competitiveness (Porter and Kramer 2002), claim that companies can improve their longterm performance by connecting the company's financial and societal goals. They further argue that a strategic approach to corporate philanthropy can align both economic and social objectives (Porter and Kramer 2002). Through strategic CSR a company could make most significant societal and environment impact and harvest the greatest business benefits (Porter and Kramer 2006). Husted and Allen (2010) argue that companies that include social action programmes in the strategic decision-making process achieve better results in economic and social value creation (Husted and Allen 
2010). Moreover, strategic CSR could allow companies to achieve a unique business position through differentiation from competitors in a way that lowers costs or better serves a particular set of customer needs (Porter and Kramer 2006). However, because of the increasing stakeholder pressure and benefits that CSR brings, a company's survival in modern society 'seems to require an awareness of social responsibility as an indispensable part of strategy' (Galbreath 2006). Therefore, today there are hardly any major consumer products companies that do not actively innovate to develop socially responsible products (Iyer and Soberman 2016). Being socially responsible is much more important than ever before.

\subsection{The link between innovation and CSR}

CSR initiatives are meant to be applied to all company activities and business and, therefore, also to innovation processes. Nevertheless, although some companies explore potential benefits of linking innovation and CSR, many businesses perceive investment in CSR as an unnecessary and costly burden (Porter and Kramer 2006). Higher costs due to the trade-off between returns from traditional business models and the cost of changes into responsible innovation practices and investment constraints are an argument for disconnecting CSR and innovation, particularly among small and medium-sized enterprises (SMEs) (Gurzawska et al. 2015; Gurzawska, Mäkinen et al. 2017). As a result, innovation activities are usually excluded from a company's responsibility agenda. There are several reasons for this situation and arguments against them, including the extent to which innovation and CSR overlap and the question of whether and how responsible innovation practices pay off, whether through value creation, competitive advantage, strengthening companies' reputation, enhancing the company's networks and stakeholder relationships, and therefore expanding intangible resources such as knowledge, co-creation and innovation capability. This section discusses these arguments and proposes a counterbalance for these claims.

\subsubsection{Conceptual perspective}

From a conceptual point of view not every corporate innovation should be perceived through the lens of responsibility, nor should CSR be solely focused on innovation. This is because not every corporate innovation raises societal, ethical, human rights or environmental issues. At the same time, CSR covers all aspects of a company's activity but does not exclusively relate to a company's innovation activities, thus CSR tools or actions are generally not designed specifically for innovation. Nevertheless, the sphere where these two concepts converge allows for the search for responsible corporate innovation. Figure 3.3 demonstrates the relationship between corporate innovation and CSR, showing the responsibility juncture. 


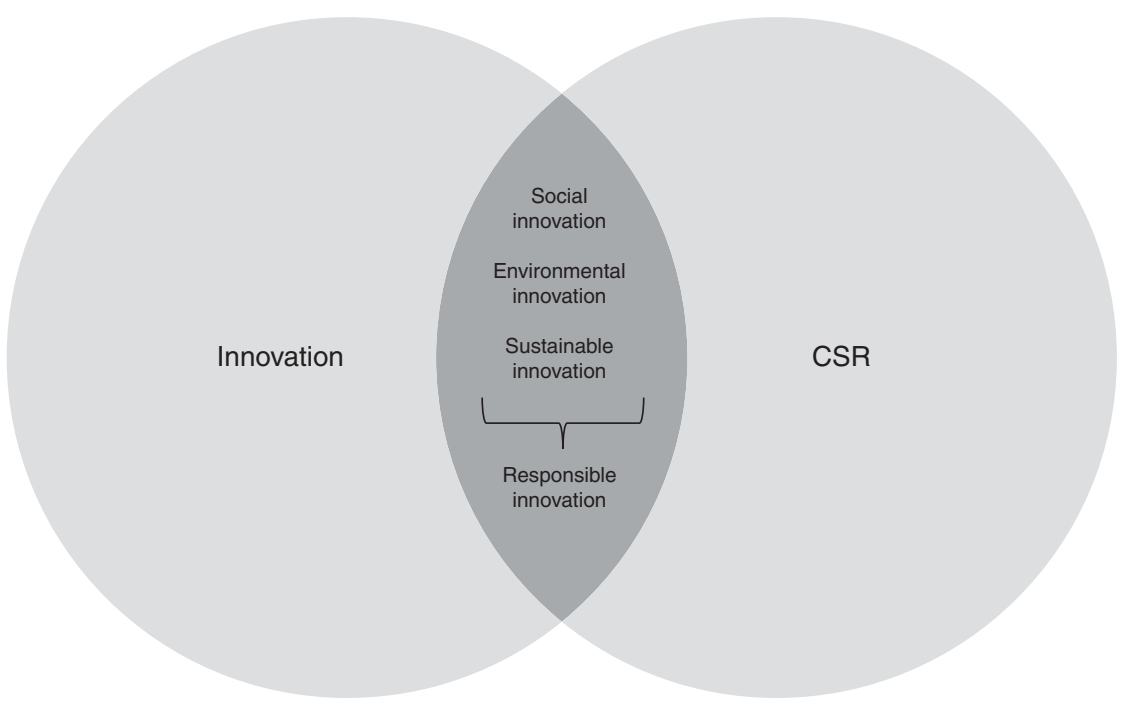

Figure 3.3 Conceptual relationship between corporate social responsibility (CSR) and innovation.

The merging point of corporate innovation and CSR encompasses a variety of well-known concepts that capture responsible innovation in various forms. Over the last 20 years, we have witnessed an expansion of literature, business activities and cross-sectoral exchanges, deliberately engineering societal and environmental responsibilities and objectives. As a result, several responsible innovation concepts exist that tackle various aspects of corporate responsibility. Social innovation, environmental and eco-innovation and sustainable innovation are among the most commonly discussed. Social innovation has been mainly developed by practitioners to 'meet pressing social needs and to improve human and environmental well-being' (Choi and Majumdar 2014). In the business context, it can be defined as a process where companies take 'community needs as opportunities to develop ideas and demonstrate business technologies, to find and serve new markets, and to solve long-standing business problems' (Kanter 1999). Environmental and eco-innovation is an innovation that reflects the concept's explicit emphasis on a reduction of environmental impact (OECD 2009). Regarding sustainable innovation, as emphasised by Adams et al. (2016), a variety of conceptualisations of sustainable innovation exist; however we lack a clear definition of sustainability. This confusion is reinforced by an array of labels applied to sustainable innovation, such as CSR; green, eco- or ecological innovation; social environmental management; and responsible innovation (Adams et al. 2016). While some authors argue for a responsible approach and give equivalence to environmental, social and economic 


\section{Agata Gurzawska}

dimensions in sustainability (Hansen et al. 2009; Longoni and Cagliano 2018), the majority of previous work focuses on ecological sustainability such as eco-innovation and environmental innovation (Carrillo-Hermosilla et al. 2010) and often overlooks the social dimension (Adams et al. 2016). Moreover, Lubberink et al. (2017) point out that the social, political and ethical implications of possible solutions are not part of the sustainable innovation discourse and practice. Nevertheless, the sustainable innovation literature provides attempts to connect sustainability with business models and strategies (Boons et al. 2013; Koistinen et al. 2018), which should be acknowledged. For instance, Iñigo and Albareda (2016) propose a sustainable innovation framework from the complex adaptive system perspective that aims to explain how firms engage and experiment. The authors conceptualise sustainable innovation around five components: operational, instrumental, collaborative, organisational and holistic; the interaction between these components is characterised by non-linearity, self-organising and emergence (Iñigo and Albareda 2016). Patala et el. (2016) build a process framework, which consists of: (1) the identification of potential impacts; (2) the identification of customer value creation mechanisms; (3) the choosing of key indicators; (4) life cycle value modelling; and (5) the demonstration of life cycle value.

Recently, academics and policy makers often refer to responsible innovation in the context of RRI. The most well-known definition of RRI by Von Schomberg (2013) defines RRI as:

a transparent, interactive process by which societal actors and innovators become mutually responsive to each other with a view to the (ethical) acceptability, sustainability and societal desirability of the innovation process and its marketable products (in order to allow a proper embedding of scientific and technological advances in our society).

(Von Schomberg 2013)

Besides Von Schomberg's definition, there is a variety of other definitions and approaches to RRI and RRI is operationalised in different ways (Sutcliffe 2011; Stilgoe et al. 2013; Taebi, Correlje et al. 2014; Foley, Bernstein et al. 2016; Lindner, Kuhlmann et al. 2016; Burget, Bardone et al. 2017; Ribeiro, Smith et al. 2017; Reber 2018; Rip 2018). With regard to further specification of RRI dimensions, there are those that tend to recur in various interpretations of the concept, and those that are more idiosyncratic (Gurzawska, Mäkinen et al. 2017). Responsible innovation in the RRI context is thought to focus on inclusion (also called engagement, or involvement of society), anticipation (assessment at an early stage in research and innovation (R\&I) of benefits and risks), reflexivity (reflecting on values and beliefs during R\&I) and responsiveness (the ability to change routines, structures and systems to adapt to changing circumstances and new insights: Gurzawska, Mäkinen et al. 2017). The European Commission has provided RRI orientation in the 
form of six policy keys, i.e. RRI is R\&I that: (1) fosters R\&I processes that are collaborative and multi-actor; (2) incorporates ethical principles so as to ensure compatibility with fundamental values; (3) promotes science literacy and science education; (4) promotes gender equality; (5) promotes open access to scientific knowledge; and (6) is guided by transparent, accountable and coherent multi-stakeholder governance (European Commission 2012). Therefore, responsible innovation should be societally desirable, sustainable and ethically acceptable (von Schomberg 2013). RRI and CSR share an emphasis on companies' responsibilities towards social goods as well as on stakeholder engagement. Nevertheless, despite some similarities, the concepts are somehow different (Gurzawska, Mäkinen et al. 2017). Firstly, while RRI is largely a top-down approach created in the policy world (e.g. Horizon 2020 funding), CSR can be characterised as a bottom-up approach where CSR policies function as a self-regulating mechanism for business. Secondly, RRI focuses on ethics appraisal and potential and actual social impact; CSR rather concentrates on the impact on community and environment (Gauttier et al. 2017). Lastly, while RRI is about R\&I, CSR is generally applicable to all company activities.

Various other forms of a conjunction between CSR and innovation exist, such as social design, socially responsible design (SRD), eco-design, design for values and open innovation. While there are differences between how responsibility is conceptualised and defined in these different concepts, i.e. social innovation, environmental innovation, sustainable innovation and RRI (Lubberink et al. 2017), this chapter construes responsible corporate innovation as an umbrella term for any innovation centred around various forms of corporate responsibility, including sustainability, societal, ethical, human rights and environmental issues. A stronger understanding of scattered and often overlapping terminology can ultimately advance the integration of different disciplines. Therefore, for the purposes of this research, responsible innovation encompasses social innovation, environmental innovation, sustainable innovation, responsible innovation in the context of RRI and other concepts of innovation that centre around various forms of responsibility.

\subsubsection{Bi-directional link between CSR and innovation}

There is a considerable literature on the way in which, across different sectors and through time, companies have adjusted to the pressures and opportunities presented by the need to become more socially responsible and sustainable, taking into account stakeholder expectations and more responsible products, processes and services that reflect these changes (Maxfield 2008; Gugler and Shi 2009; Hanke and Stark 2009; Nidumolu, Prahalad et al. 2009; Berkhout 2013; Lai, Lin et al. 2015; Sánchez and Benito-Hernández 2015; Herrera 2016; Ueki, Jeenanunta et al. 2016). The European Commission believes that CSR makes companies more sustainable, competitive and 


\section{Agata Gurzawska}

innovative (European Commission (a)). It also recognises the importance of CSR in companies' ability to innovate, as well as in risk management, cost savings, access to capital, customer relationships and human resources management (European Commission (a)). Additionally, responsible innovation encourages a move beyond defensive and proactive CSR into a more rewarding synthesis between social and commercial concerns fulfilling public needs and private interests (Midttun 2009). According to Maxfield (2008), CSR activities that are tightly linked to innovation functions might bring more financial benefit than those oriented toward public relations, marketing and human resource management (Maxfield 2008).

A vast majority of CSR and strategic CSR literature focuses on the linkage between CSR and competitiveness, highlighting the need to go beyond mere window-dressing work and investing in strategic CSR. In this view strategic CSR is linked to innovation and therefore depends on an 'innovative way to enhance efficiency in a socially friendly manner' (Gugler and Shi 2009). Grayson and Hodges (2017) explain that CSR creates largely untapped opportunities for product innovation, market development and non-traditional business models (Grayson and Hodges 2017). Moreover, CSR plays a role in differentiation strategies at the product and company levels through innovation, for example, by developing products that are socially responsible, as has been done by companies such as Ben \& Jerry's, the Body Shop and Health Valley (McWilliams and Siegel 2000). The relationship between CSR and innovation appears to be bi-directional. On the one hand, companies can use social programmes as a way to foster product and process innovation (Kanter 1999). In addition, social and environmental programmes may help generate competitively valuable resources for the company (Sharma and Vredenburg, 1998). On the other hand, companies that have an ability for continuous innovation are more likely to be able to leverage that same resource in other arenas, such as the development and implementation of social strategy. McWilliams and Segal (2000) argue that CSR and R\&D investment are highly correlated, since many aspects of CSR create either a product or process innovation (McWilliams and Siegel 2000). According to the study on the connection between CSR and company innovation by Luo and Du (2015), the positive relationship is stronger for companies with higher R\&D investment and where companies operate in more competitive markets (Luo and Du 2015).

According to MacGregor and Fontrodona (2008) there is a bi-directional system between CSR and innovation based on CSR-driven innovation and innovation-driven CSR (MacGregor and Fontrodona 2008). The authors point out that CSR-driven innovation is about 'doing the rights things', and innovation-driven CSR is about 'doing things right' (MacGregor and Fontrodona 2008). Findings of the pan-Nordic project 'CSR-driven innovation' point out that, while some companies identify the societal or environmental need before beginning to think about the business model and profit generation, for other companies social performance is a means for 


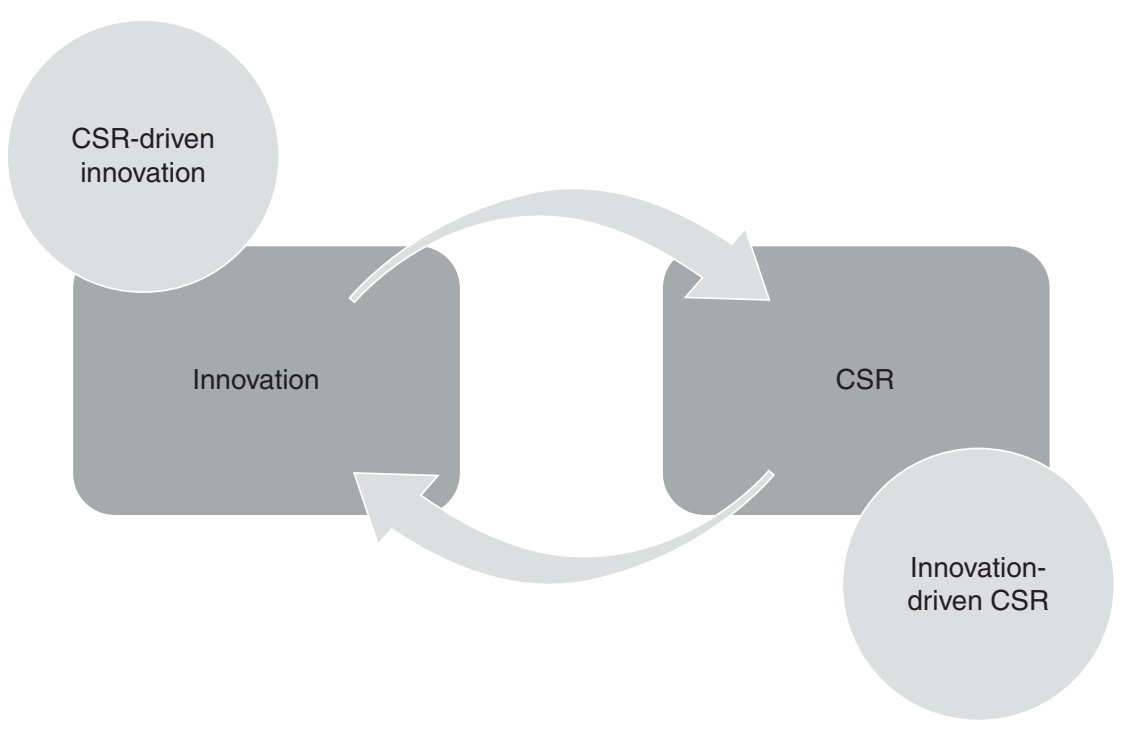

Figure 3.4 Bi-directional relation between corporate social responsibility (CSR) and innovation. (Adapted from MacGregor and Fontrodona 2008.)

achieving the goal of creating private profit (Hockerts, Morsing et al. 2009). Therefore, CSR-driven innovation is a situation when a socially or environmentally important need contributes to the creation of a new innovative product, service or process; and innovation-driven CSR refers to a situation when a technological innovation that already exists allows it to be used to achieve an important societal or environmental goal (Pyszka 2012).

Figure 3.4 presents this two-way spiral model of CSR and innovation based on CSR-driven innovation and innovation-driven CSR, that I discuss in the next subsections.

\subsubsection{CSR-driven innovation}

Globalisation, particularly thanks to the internet, has brought tremendous changes for most companies and society. Internet-connected stakeholders have become more aware of the products, services and processes that companies can offer and their marketing practices. This has caused an increase in stakeholder pressure on companies to take greater responsibility as part of their corporate citizenship. As a consequence, companies more often innovate in order to find solutions for current and emerging societal and environmental challenges. This phenomenon is known as CSR-driven innovation. CSR-driven innovation is 'an innovative process which aims at designing a profitable product or service which in an innovative and 
user-oriented way can prove beneficial to the surrounding environment and society' (Nordic Innovation Centre 2010). Companies that invest in CSR-driven innovation are characterised by 'the willingness and the capacity to discover, adopt, evaluate and exploit new technologies, products, services or processes for environmental and societal benefit' (Brik 2007). The literature discusses CSR-driven innovation referring to corporate social innovation (CSI), bottom of the pyramid (BOP) innovation, eco- and environmental innovation and social entrepreneurship (Rexhepi, Kurtishi et al. 2013). CSR-driven innovation aims at 'creating a successful business by having sustainability as a focal point when developing a new product or service' (Nordic Innovation Centre 2010). These innovative products or services may tackle such societal and environmental problems as global warming, poverty or diseases. An example is the case of the United Nations Development Project (UNDP) that has introduced the first eco-driving simulator among transport drivers in Azerbaijan, aiming to reduce the carbon emission footprint and make environmentally friendly driving habits more mainstream through training and the application of smart technologies (UNDP 2018).

Helping to address global problems may also be profitable for business. Many businesses, therefore, have already implemented a new approach to innovation, as in the case of Digital Green, addressing poverty by connecting smallholder farmers with their peers via video training conducted in local languages (Digital Green ). In the automotive industry, CSR-driven innovation is about investment in long-term innovations that will reduce the threat of climate change, including electric, hybrid, fuel cell and solar vehicles (Khaledabadi and Magnusson 2008). The energy sector is exploring alternative sources of energy, including solar panels, wave power, wind turbines and bioenergy. One of the energy sector CSR-driven innovations is the US company SolarCity, which from 2008 was providing comprehensive solar power solutions for energy-efficient lighting as part of a sustainable cities initiative. Thanks to integrated sales, financing, design, installation, monitoring and efficient services, customers could get cleaner and more affordable energy. In 2016 the company merged with Tesla Inc. and introduced the Tesla Solar Roof based on solar roof tiles, made of glass (Tesla ).

Moreover, companies develop innovation and business models based on consumers' preferences regarding social responsibility (Iyer and Soberman 2016). CSR-driven innovation may create an environment in which consumers identify with a product or service or brand because of its socially responsible approach, ultimately creating a strategic business model based on responsible innovation. One example of a company placing responsibility at the core of its business is Fairphone. This Dutch social enterprise engages in fairer electronics by developing a business model that puts ethical values first (Fairphone (a)). Fairphone produces repairable and recyclable phones made of conflict-free minerals (natural resources not extracted in a conflict zone and sold to perpetuate the fighting), manufactured with respect 
for workers' rights and wellbeing. The Fairphone community consists of 100,000 owners of fair smartphones, over 136,000 fans on Facebook and thousands of Twitter and Instagram followers (Fairphone (b)). Nearly every aspect of the company's value chain reinforces the societal and environmental dimensions of its value proposition, distinguishing Fairphone from its competitors.

Another example is Lush Fresh Handmade Cosmetics (Lush Cosmetics), a British cosmetics business with a global brand. Lush offers $100 \%$ vegetarian cosmetics no-packaging-required and when packaging is unavoidable, they use recyclable or compostable packaging. The company supports human rights, environmental conservation and animal welfare through (for instance) developing a palm oil-free soap base. ${ }^{1}$

The last example of a strategic business model based on responsible innovation is a Dutch company called Rural Spark. Rural Spark provides a smart energy grid based on the concept of smartly distributed energy networks for rural villagers. For a monthly subscription, villagers rent a Rural Spark energy kit and become local energy suppliers who generate, use and sell energy (Rural Spark). Rural Spark provides access to clean, safe and sustainable energy; it also leapfrogs the outdated, top-down centralised energy grids and empowers users and encourages entrepreneurship (Rural Spark).

\subsubsection{Innovation-driven CSR}

Empirical studies confirm that R\&D-intensive companies are more competitive on the market (Kinkel, Lay et al. 2005). R\&D is a part of innovation situated at the front end of the innovation life cycle. Studies by McWilliams and Siegel (2000) and Bansal (2005) show a positive correlation between CSR and R\&D intensity 'because both are associated with product and process innovation' (McWilliams and Siegel 2000). Other studies, such as those by Bouquet and Deutsch (2008) and Hull and Rothenberg (2008), seem to confirm this correlation. Padgett and Galan (2010) extend these findings and show that R\&D intensity positively affects CSR in a way that R\&D is perceived as a form of investment resulting in increased knowledge that leads to product and process innovation (Padgett and Galan 2010). Furthermore, they claim that these innovations can lead to CSR-related processes and products (Padgett and Galan 2010). This model is known as innovationdriven CSR. It is a situation in which a technological innovation already exists and can be used for the realisation of societal and environmental objectives. Therefore, it is a technological drive or an entrepreneur's desire to develop new products that drives the innovation (Hockerts, Morsing et al. 2009). However, through the innovation processes, a company may improve its effectiveness and efficiency, e.g. through minimising its $\mathrm{CO}_{2}$ footprint and water footprint and/or reducing the number of casualties or fatal accident rates. These actions, as Padgett and Galan (2010) claim, should be taken into consideration when developing companies' CSR strategies, because 
process and product innovations may already be involved in CSR activities (Padgett and Galan 2010). Therefore, the authors suggest that an

innovative firm should focus their efforts on identifying opportunities in their R\&D processes to initiate related CSR activities. This will allow the company to manage costs more effectively and determine whether other CSR activities might be necessary to meet stakeholder expectations.

(Padgett and Galan 2010)

Innovation-driven CSR is a new phenomenon that requires further empirical study on its functioning and consequences. Nevertheless, it shows that the interconnectedness of CSR and innovation is not linear, but this process is more complex as there are numerous feedback loops. CSR has an indirect influence on innovation. It may give rise to new products and processes. Innovation, however, can also influence CSR instruments.

\subsubsection{CSR, innovation and value creation}

Companies engage in social responsibility and go 'beyond compliance' for various reasons, including market demand, cost advantage, differentiation strategy, upgrading strategy, to build intangible brand value around social responsibility or sustainability reputation, to reduce regulatory and other risks (Berkhout 2013). According to Burke and Logsdon (1996) 'the ultimate measure of strategic benefits from CSR activities is the value they create for the firm', where value creation is understood as having identifiable, measurable economic benefits that the company expects to receive (Burke and Logsdon 1996). Value creation is crucial for strategic success (Tantalo and Priem 2016).

Burke and Logsdon (1996) identify five CSR behaviours that bring strategic benefits: (1) philanthropy (e.g. engineering research fellowship and community support), ensuring customer loyalty and future purchasers; (2) direct or indirect employee benefits (e.g. flexible working hours, health and wellness) may improve productivity through improved employee loyalty and morale; (3) environmental management may lead to product and process innovation (e.g. new 'green' products) and improved public relations and/or marketing advantage, ultimately opening up new markets; (4) through a political activity companies may achieve favourable changes in economic or social regulations and create new market opportunities or geographical market opportunities; and lastly (5) product- or service-related characteristics, innovations or processes such as product reformulation (e.g. improved 'green' design) may lead to new markets, first-to-market or leadership benefits and provide edge in meeting emergency needs (Burke and Logsdon 1996).

Lubin and Etsy (2010) claim that CSR-related issues are one of the socalled 'megatrends' that create incipient societal and economic shifts, such 
as globalisation, the rise of the information society and the move from hierarchical organisations to networks. These transformations arise from technological innovation or from new ways of doing business (Lubin and Esty 2010). Nowadays, thousands of companies are placing strategic bets on innovation in CSR-related issues such as renewable power and pollution control (Lubin and Esty 2010). This would not be possible without innovative technologies and business approaches. In the sustainable innovation literature stream, strongly sustainable business models do no harm but create positive environmental, social and economic value (Koistinen et al. 2018). Accordingly, strongly sustainable companies take financial, societal and environmental costs into account and measure financial rewards, social benefits and environmental regeneration (Koistinen et al. 2018). Nevertheless, value should be created to the whole range of stakeholders and the natural environment (Koistinen et al. 2018).

In line with this assertion, Patala et al. (2016) introduce a concept of sustainable value propositions as 'a promise on the economic, environmental and social benefits that a firm's offering delivers to customers and society at large, considering both short-term profits and long-term sustainability' (Patala et al. 2016). From the system's point of view, we should consider value creation as not only economic, but as a psychological, sociological and ecological concept, which includes value for the organisation, customers, ecosystem and society (Den Ouden 2011).

Value creation through responsible corporate innovation can be placed in a broader discussion on measurable benefits of CSR. Financial benefits of responsible corporate behaviour can be found particularly in the areas of human resources, reputation and branding, reduction of risk and operational cost (McElhaney 2009). Moreover, Gugler and Shi (2009) claim that the economic interests offered by CSR, such as better access to market, finance and business; enhanced intangible assets, reputation, community relations; and reduced risk from regulatory sanction could encourage companies to structural changes, including innovative processes and technological upgrading. As a result, these transformations enhance productivity and efficiency, and ultimately compensate for the initial costs and enable competitiveness (Gugler and Shi 2009). Nevertheless, the discussion on the relationship between CSR and a company's performance seems to be unresolved. While some studies disagree on the link between corporate social performance (CSP) and corporate financial performance (CFP), some seem to indicate the existence of a positive relationship between CSP and CFP (Margolis and Walsh 2003; Orlitzky, Schmidt et al. 2003, Carroll and Shabana 2010; ING 2018), while some other studies point out inconsistencies (Griffin and Mahon 1997; Roman, Hayibor et al. 1999).

According to the study by Bonini et al. (2009), CSR-related programmes create measurable value through return on capital, risk management and quality of management and growth. This study is particularly interesting in the context of CSR and innovation, showing that companies' growth is 
ensured thanks to opportunities to access new markets and new customers, cutting-edge technologies and innovative products/services for unmet societal or environmental needs and the possibility to use these products/services for business purposes, such as patents and proprietary knowledge that ultimately lead to higher brand loyalty, reputation and goodwill with stakeholders (Bonini, Koller et al. 2009). Therefore, innovation is one of the key pathways through which CSR creates measurable business value (Bonini, Koller et al. 2009).

Similar findings can be found in the study by Husted and Allen (2010), who emphasise that 'the firm's social projects allow it to achieve measurable social objectives as well as improved corporate financial performance when the social action is linked to product and service innovation, process innovation, or corporate reputation' (Husted and Allen 2010). Martinez-Conesa et al. (2017), in their recent study, argue that 'innovation may help to ensure the sustainability of a more responsible approach to business, resulting in system level solutions that are at the same time, responsible and profitable' (Martinez-Conesa, Soto-Acosta et al. 2017). Therefore, it is crucial for companies to integrate different business activities and tie them in with the firm strategy as this is the only way to generate value (Martinez-Conesa, SotoAcosta et al. 2017).

\subsubsection{Responsible innovation and stakeholder management}

However, to generate value companies need to transform their approach to CSR from a bolt-on activity to built-in to business strategy activity supporting business purpose and objectives (Grayson and Hodges 2017). Studies by Husted et al. (2007) show that a company's resources for continuous innovation are significantly related to the use of strategic social positioning. According to a study by Luo and Du (2012), in companies where CSR is not a peripheral activity, it can become a pivotal component of competitiveness and growth. As a result CSR programmes can make a company more innovative (Luo and Du 2012). In their study of 128 companies in all major industry sectors, they found that companies that are in the top third in terms of CSR activities brought out, on average, 47 new products a year, while companies in the bottom third brought out only 12 (Luo and Du 2012). The authors conceptualise that the reason for this is the fact that CSR builds broader and deeper relationship networks with external stakeholders, such as customers, suppliers, non-governmental organisations (NGOs) and governments, facilitating the sharing and exchange of external knowledge of its stakeholders (Luo and Du 2012, 2015). From the strategy point of view, stakeholders' external knowledge complements the company's internal knowledge and promotes a company's innovation (Luo and Du 2015).

According to Hanke and Stark (2009) the internal culture of a company (e.g. the way human resource development and organisational learning processes are performed) affects the level of innovation and the 
organisation's development with respect to its environment. For instance, in the context of sustainable vehicles, governmental regulations can foster innovations in sustainable vehicles; at the same time, sustainable vehicle development can foster environmental regulations (Khaledabadi and Magnusson 2008). Therefore, the relationship between the company and its key external stakeholders (e.g. customers, governments, society) enables each sector to gain profit by mutual learning and exchange, and through developing CSI (Hanke and Stark 2009).

Amos and Awuah (2017) argue that a company could achieve its strategic objectives and improve competitiveness when blending in the potential of stakeholders. A company may achieve a unique competitive position in the local market through a collaboration with stakeholders (e.g. the local community and NGOs), at the same time creating and delivering societal and economic benefits (Amos and Baffour Awuah 2017).

The integration of CSR and multiple stakeholders into innovation activities leads to new innovations (Hansen et al. 2009) and bundles of products and services that suit local market conditions. As discussed in the previous subsection, responsible innovation is about creating value for the organisation, customers, ecosystem and society (Den Ouden 2011). Responsible innovation calls for integration of stakeholders, especially the people who might be affected by the innovation (Adams et al. 2016; Lubberink et al. 2017). From a business strategy perspective, the success of innovations depends ultimately on consumers' acceptance and, therefore, to succeed a company firstly needs to understand customer needs and then develop products that meet those needs (Hauser, Tellis et al. 2006). Innovation is about identifying opportunities and creating strategies to fulfil customer needs and expectations (Husted and Allen 2010). Responding to customers' social needs may stimulate innovation (Husted and Allen 2010). These findings strongly reflect one of the approaches to CSR, namely stakeholder theory that focuses on 'managing potential conflict stemming from divergent interests' (Frooman 1999).

Furthermore, companies with a strategic priority to innovation can use CSR as an effective means to reduce information asymmetry between themselves and stakeholders (Shen, Tang et al. 2016). Moreover, the development of regional and supra-regional networks and efficient network governance of different actors may be vital for an innovative and sustainable CSR strategy (Hanke and Stark 2009). Unsurprisingly, Husted and Allen (2007) found that there is a high correlation between stakeholder integration and continuous innovation (Husted and Allen 2007). Nevertheless, connecting innovation and CSR raises some challenges and uncertainties, which are discussed in the next subsection.

\subsubsection{Challenges and limitations in connecting CSR and innovation}

The link between CSR and innovation is a relatively new topic. Midttun points out that innovation and CSR are complex, multidimensional phenomena/ 


\section{Agata Gurzawska}

concepts/fields (Midttun 2006). He identifies an incompatibility between the dynamic nature of innovation and the static character of CSR. Therefore, he calls for a dynamic reinterpretation of CSR which can be better aligned with the 'disruptive' innovation literature. This approach may also 'provide important insights into the socio-economic realignment necessary to accommodate new technology and business models' (Midttun 2006). Furthermore, despite some theoretical considerations, the empirical evidence is scarce and inconclusive (Gallego-Alvarez, Manuel Prado-Lorenzo et al. 2011; Luo and Du 2015; Shen, Tang et al. 2016; Halkos and Skouloudis 2018). On the one hand, empirical studies on the relationship between CSR and innovation by Gallego-Alvarez et al. (Gallego-Alvarez, Manuel Prado-Lorenzo et al. 2011) show that the bi-directional relationship between CSR and innovation is negative. These findings seem to be endorsed by Halkos and Skouloudis (2018). On the other hand, findings by Luo and Du (2015) and by Shen et al. (2016) demonstrate that CSR activities boost innovation. Moreover, the pan-Nordic project 'CSR-driven innovation' presents several success stories of businesses engaged in CSR-driven innovation. We lack synergies in a system approach, between the external (a system-level) and internal business (a company-level) environments to achieve responsible corporate innovation. There should be an interplay between policy-oriented external environments (e.g. legal and governance frameworks) and business strategy change, for instance through cooperation between the public and private sectors in the form of private-public partnerships (Koistinen et al. 2018).

Taking into consideration that responsible corporate innovation management raises both opportunities and challenges, further studies are required, particularly empirical studies, to investigate the nature, benefits and challenges, measurement metrics and business models for responsible innovation. While difficulties remain, undoubtedly some of the most successful corporations are also among the most socially responsible.

\subsection{Strategic responsible innovation management (StRIM)}

When considering the opportunities and benefits of linking innovation and CSR, this study proposes a new approach, called strategic responsible innovation management (StRIM). I argue that a responsible innovation strategy model based on the commitment of the company, in conjunction with the strategic use of responsible innovation, can lead to a competitive advantage and value creation, while incorporating key market and non-market stakeholders. In developing the model, I build on the concepts discussed in Section 3.3: innovation management; strategic CSR(including Husted and Allen's seven-step model of corporate social strategy); recent developments in business models in the sustainable innovation literature stream (including models by Hansen 2009; Iñigo and Albareda 2016; Patala et al. 2016 ); value creation; CSR-driven innovation and innovation-driven CSR; and the multi-stakeholder approach. 
Deriving from RRI, I argue that responsible corporate innovation is a strategic concept (Von Schomberg 2013; Lindner, Kuhlmann et al. 2016) related to strategic CSR that imposes several demands on the way in which innovation is organised. Firstly, innovation should be guided by the principles of good governance, which includes anticipation, openness and transparency. Secondly, responsible innovation requires the participation of a variety of stakeholders in the innovation process. Thirdly, societal and environmental issues should be carefully considered, evaluated and controlled throughout the innovation process. Responsibility should be embedded in both the process of innovation (e.g. fair labour conditions, ethical sourcing, avoiding animal cruelty) as well as its outcomes (e.g. run-tracking device ensuring users' privacy, non-discriminatory software systems for predictive policing). If innovation could lead to negative societal or environmental consequences or conflicts with ethical criteria, including the fundamental values that societies uphold in their constitutions and legal frameworks, mitigation actions should be undertaken (Gurzawska, Mäkinen et al. 2017).

The StRIM approach is built on the traditional strategic management process. The strategic process of a company has three components: (1) planning; (2) implementation; and (3) evaluation and control (White and Bruton 2010). These activities should be performed simultaneously and continuously. A successful company should manage its strategies in three main areas: (1) the company's internal environment, including resources and capabilities; (2) the external environment within which the organisation operates; and (3) the company's ability to add value to what it does (Lynch 2015). The internal environment involves departments, management teams and individual employees, but also resources and capabilities that form the company. The external environment refers to external forces that impact the company. Figure 3.5 presents the strategic management scheme based on a system approach presenting the company as an association of interrelated and interdependent parts (White and Bruton 2010).

The systems approach to StRIM involves a framework of strategic process components and three main areas that the company needs to manage and feed back during the entire process. Decisions made on each stage of the strategy (planning, implementation and evaluation and control) feed back into the internal environment, resources and capabilities; the external environment; and value creation. Changes in the company's internal environment (e.g. reorganisation in the $\mathrm{R} \& \mathrm{D}$ department, new more sustainable production methods, changes in a company's identity and a culture embodied in a new code of conduct); the external environment (e.g. new customer group, new legal regulations on $\mathrm{CO}_{2}$ emission threshold); and in the value the company creates will all have an impact on subsequent strategic decisions which are represented in the scheme. This approach reflects the non-linearity of the process with a bi-directional link between innovation and CSR with feedback loops. The next subsections discuss individual stages of the StRIM approach. 


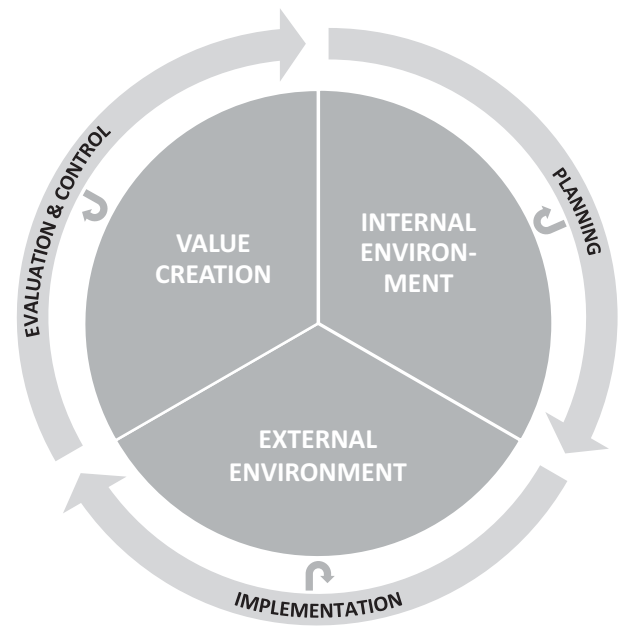

Figure 3.5 Strategic responsible innovation management (StRIM) scheme. (Adapted from White and Bruton, 2010, and Lynch, 2015.)

\subsubsection{Planning}

Starting from the outer circle, planning of the strategy includes strategic analysis and strategic development.

In the strategic analysis phase, a company should examine the internal and external environment and the links between them and identify its vision, mission and objectives (Lynch 2015). In the internal environment analysis, a company should explore the internal resources (tangible and intangible) and capabilities, what their role is, added value and competitive advantage and how they can be improved over time (Lynch 2015).

The internal environment consists of the company's culture, structures and processes. Adapting Husted and colleagues' approach to social strategy, StRIM requires the integration of strategic business and strategic responsibility actions (Husted, Allen et al. 2015). While business strategies employ a company's resources and capabilities to achieve purely market-based competitive objectives (Husted, Allen et al. 2015), StRIM would use a company's resources and capabilities to meet both financial as well as societal and environmental objectives. Therefore, the purpose of StRIM is to create value for the company, especially economic value, by embracing societal and environmental objectives. Responsible innovation and corporate responsibility can be perceived as specific intangible resources that provide benefits to companies (McWilliams and Siegel 2011). Components of corporate culture, such as corporate values and philosophy, are specific resources essential to a company's identity (Albert and Whetten 1985). They can provide 
a competitive advantage and help in inclusion of non-economic objectives within a company's strategy (Husted and Allen 2007). The company's culture and identity should be evaluated in terms of societal and environmental needs and opportunities (Husted and Allen 2010). The successful integration of innovation with strategic concerns should begin with a company's capabilities, because the business ultimately develops its competitive advantage through capabilities (Barney 1991). Capabilities are skills that a company develops (White and Bruton 2010). The capabilities of a company can be classified as either technical or market capabilities. Technical capabilities address how the company approaches technology it already has or wishes to have in the future, and market capabilities are market-relevant skills that indirectly impact the technology of the company (White and Bruton 2010).

The external environment analysis determines what is happening or is likely to happen outside the company (external environment), including societal and environmental risks and opportunities, competitive environment and relationships with non-market stakeholders. In this stage, a company should identify external factors that could affect or be affected by the innovation process, for instance, economic, political and technological developments, potential alliances, networks and partnerships leading to sustainable co-operation, competitors and customers' preferences. The external environment analysis is crucial, because a company can impact or be impacted by its broader environment (White and Bruton 2010). Based on the internal and external environment insights, a company should develop and review its vision, mission and strategic objectives.

The second part of planning is the strategic development that involves the identification and rational selection of options available to achieve the agreed objectives and determination of the strategy, its structure and style (including organisational structure and people) (Lynch 2015), taking into consideration value creation. These objectives should be intrinsic with a company's resources and capabilities, mission and vision and the external environment.

As discussed above, responsible innovation requires embedding the principles of good governance that include anticipation, openness, transparency, and accountability in the corporate vision, mission, objectives and corporate culture rooted in beliefs and value systems shared by employees. Moreover, relevant internal and external stakeholders should be engaged in responsible innovation planning. They can improve the quality of the environmental analysis and strategic development, providing specific knowledge and experience, and through communicating their preferences, needs and concerns. Nevertheless, the company should manage and prioritise these various interests.

\subsubsection{Implementation}

The implementation stage is a process of applying the chosen strategy in practice. The success of the implementation stage depends on three specific policies and practices: a company's formal organisational structure, its formal and 
informal management control systems and its employee compensation policies (Hesterly and Barney 2008). Responsible innovation should be integrated along the whole value chain and, therefore, into the governance of the company and into existing management systems (Gurzawska, Mäkinen et al. 2017). Efforts to create innovations that are socially and environmentally responsible should be treated and managed as core business strategy, just as are the strategies of capital expenditure, talent management and marketing. Responsible innovation principles that are embedded in the governance of a company might improve integration of the vision, mission and objectives of the company's personnel with those of the corporate policy (Chatfield, Borsella et al. 2017).

Senior leadership and management of the company should organise innovation internally to pursue responsible practices and behaviours when developing new products, processes and services (Responsible-Industry 2017). Responsible corporate innovation has little effect on strategy if individuals and leaders within the organisation are not committed to responsible behaviour. Therefore, senior leadership and management of the company, including the board of directors, must make an authentic, firm and public commitment to responsible innovation efforts, and engage with them (McElhaney 2009). A clear commitment towards responsible innovation principles can build a consistent picture of corporate values as an ideological system that aligns employees to strategic objectives and binds them to these corporate goals (Berkhoud 2013). Aligning employees' values with organisational values can support and nurture responsible innovations (Chatfield, Iatridis et al. 2017). According to Grant (2007) a company that cares about user needs and societal welfare can spark motivation, positively affect employees' actions and behaviour (Grant 2007), enhance their sense of having 'meaningful work' and enhance employee engagement (Gurzawska, Mäkinen et al. 2017). It is not only beneficial for an employee, but also for a company. This is because employee engagement is correlated with higher productivity, costs and sales, which are the main performance indicators (Gurzawska, Mäkinen et al. 2017). A company can incentivise employees to pursue responsible corporate innovation, because a properly designed reward and incentive system is crucial for creating motivation and commitment (De Kluyver and Pearce 2006). A company can do this through awareness raising, an integration of ethical thinking into the design/production process, advocating and encouraging employees to maintain a responsible attitude and discouraging/stigmatising unethical behaviour (Responsible-Industry Project Consortium, 2017 BiB114; Gurzawska, Mäkinen et al. 2017). Management should also adopt social responsibility governance tools to support the strategy implementation. These tools should be based on co-creation and shared responsibility of all stakeholders (Gurzawska, Mäkinen et al. 2017).

\subsubsection{Evaluation and control}

A strategy is effective when it creates value for shareholders, partners, suppliers, employees and the community, yet it delivers customer value by 
satisfying their needs, including societal and environmental needs, better than rivals. The evaluation and control stage focuses on monitoring innovation to ensure that it meets the desired outcomes and creates value, both financial and social. It is necessary that after an innovation is implemented, the company monitors changes that may affect innovation, making it irresponsible and unethical, technologically obsolete, replaceable or competitively weak (White and Bruton 2010).

Every company should measure its performance and created value. Performance metrics serve as a powerful management tool in ensuring that the company focuses on accomplishing its mission and objectives and creating incentives for staff and managers (Sawhill and Williamson 2001). As discussed in Subsection 3.3.3, innovation linked to CSR is one of the key ways through which a company can achieve measurable social objectives and create measurable business value. Nevertheless, the responsible innovation metrics should be selected carefully to support the strategy, otherwise the strategy cannot be delivered. The key here is to develop metrics based on the company's context which is not only internal but also relevant to its key external partners and ecosystems. Measuring societal and environmental objectives may be challenging; nevertheless non-profit performance metrics could provide some lessons learnt about approaches to quantifying success, even for highly ambitious and abstract goals. Sawhill and Williamson (2001) determine three kinds of performance metrics: (1) metrics measuring companies' successes in mobilising resources; (2) metrics measuring staff effectiveness on the job; and (3) metrics measuring progress in fulfilling companies' missions.

StRIM offers a more conscious and integrated approach connecting companies' innovation and CSR strategies. It could help to arrange patterns of organisational behaviour in terms of strategising responsible corporate innovation. Following Mintzberg et al. (1998), this strategy should be developed as 'a transformational process based on learning and growth, both of the informal (culture, vision, position, people) and formal (programs, products, structure, system) parts of an organisation' (Mintzberg et el. 1998). This business strategy should be integrated with core business objectives and embedded in day-to-day business culture and operations. Furthermore, it should encourage stakeholder dialogue and 'social learning' (multistakeholder approach). Such an approach would foster the responsible development of innovations that are profitable for companies, accepted by society and relevant to societal and environmental problems. Nevertheless, a strategic approach to responsible innovation raises some challenges and uncertainties, which are discussed in the next subsection.

\subsection{Conclusions}

A specific contribution of this chapter was to develop a better account of how companies may create economic and social value through integrating responsible innovation in their strategies. This study explains how the link between innovation and CSR may assist in improving a company's competitiveness, 
value creation and stakeholder management. In this chapter, I connect innovation and CSR in order to foster the responsible development of product, process, organisation and marketing innovation. Firstly, I delineate the field by defining the concepts underpinning responsible innovation, including innovation, CSR and their relation to business strategy. This analysis allows me to provide recommendations for ways in which companies can develop strategies for responsible corporate innovation management. By identifying the key analytical factors (innovation management, responsible innovation, strategic CSR, CSR-driven innovation and innovation-driven CSR, multi-stakeholder approach) it is possible to recognise several strands or connections that help frame understanding of the relationship between innovation and CSR. Both innovation and CSR should be perceived as a strategic tool and a goal. Therefore, companies should explore innovations that are accepted by society and address societal and environmental problems. I argue that the concept of CSR enriches the innovation process by emphasising the interdependence of business and society. At the same time, CSR activities are tightly linked to innovation functions that might ensure a competitive advantage and therefore might be more profitable than those oriented toward public relations, marketing and human resource management. I propose a new approach, called StRIM, that is intertwined with companies' social responsibility. This approach is intended to redefine companies' perceptions of a 'successful innovation' by shifting the focus from a company's financial success to sustainable outcomes, for both business and society. A strategy is unique for an organisation, therefore StRIM can help to develop strategies best suited to the company's continuous success. In this way, responsible innovation will create and generate revenue, not just minimise costs and risks. The conceptual framework developed in this chapter may support companies to reflect on their relations with other parts of society. The framework may also be helpful to answer questions on CSR strategising. Nevertheless, there will be further questions on the deep-rooted values and beliefs in companies, which are responsible for the acceptance (and non-acceptance) of an organisational engagement. Hence, the conceptual framework serves as a first attempt to arrange patterns of organisational behaviour in responsible innovation strategising.

\section{Funding}

The research leading to these results received funding from the European Community's Seventh Framework Programme (FP7/2007-2013) under grant agreement no. 612231 (SATORI).

\section{Acknowledgements}

The author would like to acknowledge the contribution of all the project's participants and all the project's activities to the ideas that underpin this paper. 


\section{Copyright}

Copyright remains with the authors. This is an open access article distributed under the terms of the Creative Commons Attribution License, which permits unrestricted use, distribution, and reproduction in any medium, provided the original author and source are credited.

\section{Note}

1 The palm oil industry has been linked to deforestation, habitat degradation, climate change, animal cruelty and indigenous rights abuses in the countries where it is produced. See e.g. Say No to Palm Oil: www.saynotopalmoil.com/

\section{References}

Adams, R., S. Jeanrenaud, J. Bessant, D. Denyer, and P. Overy (2016). Sustainabilityoriented innovation: A systematic review. International Journal of Management Reviews, 18(2), 180-205. doi:10.1111/ijmr.12068.

Albert, S. and D. A. Whetten (1985). Organizational identity. In Hatch, M.J. \& Schultz, M. (Eds.), Organizational identity: A reader (Oxford Management Readers). Oxford, UK: Oxford University Press.

Amos, G. J. and G. Baffour Awuah (2017). In search of competitiveness through innovation-driven CSR initiatives in Multinational Enterprise subsidiaries in developing countries. Journal of Developing Country Studies, 7(2), 161-173.

Baker, M. J. (2014). Marketing strategy and management. Macmillan International Higher Education.

Bansal, P. (2005). Evolving sustainably: A longitudinal study of corporate sustainable development. Strategic Management Journal, 26(3), 197-218.

Barney, J. (1991). Firm resources and sustained competitive advantage. Journal of Management, 17(1), 99-120. https://doi.org/10.1177/014920639101 700108

Baron, D. P. (2001). Private politics, corporate social responsibility, and integrated strategy. Journal of Economics \& Management Strategy, 10(1), 7-45.

Basu, K. and G. Palazzo (2008). Corporate social responsibility: A process model of sensemaking. Academy of Management Review, 33(1), 122-136.

Bennett, R. C. and R. G. Cooper (1981). The misuse of marketing: An American tragedy. Business Horizons, 24(6), 51-61.

Berkhout, F. (2013). Sustainable Innovation Management. In Dodgson, M., Gann, D. M., \& Phillips, N. (Eds.), The Oxford handbook of innovation management. Oxford, UK: Oxford University Press.

Bonini, S. T. M. Koller, and P. H. Mirvis (2009). Valuing social responsibility programs. McKinsey on Finance, 32(Summer), 11-18. Retrieved from www. mckinsey.com/business-functions/strategy-and-corporate-finance/our-insights/ valuing-social-responsibility-programs

Boons, F., C. Montalvo, J. Quist, and M. Wagner (2013). Sustainable innovation, business models and economic performance: An overview. Journal of Cleaner Production, 45, 1-8. 
Bouquet, C. and Y. Deutsch (2008). The impact of corporate social performance on a firm's multinationality. Journal of Business Ethics, 80(4), 755-769.

Brik, A. B. (2007). CSR Innovation: Its antecedents and impact on market orientation. Paper presented at the AIB-UK Conference 2007, London. As cited in Gugler, P. and J. Y. Shi (2009). Corporate social responsibility for developing country multinational corporations: Lost war in pertaining global competitiveness? Journal of Business Ethics, 87(1), 3-24.

Burget, M., E. Bardone, and M. Pedaste (2017). Definitions and conceptual dimensions of responsible research and innovation: A literature review. Science and Engineering Ethics, 23(1), 1-19.

Burke, L., and J. M. Logsdon (1996). How corporate social responsibility pays off. Long Range Planning, 29(4), 495-502.

Carrillo-Hermosilla, J., P. Del Río, and T. Könnölä (2010). Diversity of ecoinnovations: Reflections from selected case studies. Journal of Cleaner Production, 18(10-11), 1073-1083.

Carroll, A. B. (1979). A three-dimensional conceptual model of corporate performance. Academy of Management Review, 4(4), 497-505.

Carroll, A. B. (1991). The pyramid of corporate social responsibility: Toward the moral management of organizational stakeholders. Business Horizons, 34(4), 39-48.

Carroll, A. B., and K. M. Shabana (2010). The business case for corporate social responsibility: A review of concepts, research and practice. International Journal of Management Reviews, 12(1), 85-105.

Chatfield, K., E. Borsella, E. Mantovani, A. Porcari, and B. Stahl (2017). An investigation into risk perception in the ICT industry as a core component of responsible research and innovation. Sustainability, 9(8), 1424.

Chatfield, K., K. Iatridis, B. Stahl, and N. Paspallis (2017). Innovating responsibly in ICT for ageing: Drivers, obstacles and implementation. Sustainability, 9(6), 971.

Choi, N., and S. Majumdar (2014). Social innovation: Towards a conceptualisation. In Majumdar, S., Guha, S., and Marakkath, N. (Eds.), Technology and innovation for social change (pp. 7-34). India: Springer. doi:10.1007/978-81-322-2071-8. Retrieved from https://link.springer.com/book/10.1007\%2F978-81-322-2071-8 (accessed 15 May 2019).

Conway, S. and F. Steward (2009). Managing and shaping innovation. Oxford, UK: Oxford University Press.

Crane, A. and D. Matten (2016). Business ethics: Managing corporate citizenship and sustainability in the age of globalization. Oxford, UK: Oxford University Press.

Dahlsrud, A. (2008). How corporate social responsibility is defined: An analysis of 37 definitions. Corporate Social Responsibility and Environmental Management, 15(1), 1-13.

Davila, T., M. Epstein, and R. Shelton (2012). Making innovation work: How to manage it, measure it, and profit from it. Upper Saddle River, New Jersey: FT Press.

De Kluyver, C. A. and J. A. Pearce (2006). Strategy: A view from the top. An executive perspective. Upper Saddle River, New Jersey: Pearson.

De Weerd-Nederhof, P. (2007). Innovation management, strategy and implementation using the pentathlon framework. Edited by Keith Goffin and Rick Mitchell. Rod Management, 37(1), 90-92. 
Den Ouden, E. (2011). Innovation design: Creating value for people, organizations and society. Springer Science \& Business Media.

Digital Green. Retrieved from www.digitalgreen.org/ (accessed: 15 May 2018).

Dodgson, M., D. M. Gann, and N. Phillips, (Eds.). (2013). The Oxford handbook of innovation management. Oxford: Oxford University Press.

European Commission (2012). Responsible Research and Innovation: Europe's ability to respond to societal challenges. Publications Office of the European Union, Luxembourg. Retrieved from https://ec.europa.eu/research/swafs/pdf/ pub_rri/KI0214595ENC.pdf

European Commission (a). Corporate social responsibility (CSR). Retrieved from http://ec.europa.eu/growth/industry/corporate-social-responsibility_en (accessed: 15 April 2018).

Fairphone (a). Retrieved from www.fairphone.com/about/ (accessed: 23 December 2017).

Fairphone (b). Retrieved from www.facebook.com/Fairphone/?fref=ts; www.fair phone.com/we-are-fairphone/ (accessed: 23 December 2017).

Foley, R. W., M. J. Bernstein, and A. Wiek (2016). Towards an alignment of activities, aspirations and stakeholders for responsible innovation. Journal of Responsible Innovation, 3(3), 209-232.

Frooman, J. (1999). Stakeholder influence strategies. Academy of Management Review, 24(2), 191-205.

Galbreath, J. (2006). Corporate social responsibility strategy: Strategic options, global considerations. Corporate Governance: The International Journal of Business in Society, 6(2), 175-187.

Gallego-Alvarez, I., J. Manuel Prado-Lorenzo, and I. M. García-Sánchez (2011). Corporate social responsibility and innovation: A resource-based theory. Management Decision, 49(10), 1709-1727.

Garriga, E., and D. Melé (2004). Corporate social responsibility theories: Mapping the territory. Journal of Business Ethics, 53(1-2), 51-71.

Gauttier, S., J. H. Søraker, C. Arora, P. A. E., Brey, and M. Mäkinen (2017). Models of RRI in Industry. Deliverable 3.3, Responsible Industry Project. Retrieved from: www.responsible-industry.eu/ (accessed: 1 May 2019).

Grant, A. M. (2007). Relational job design and the motivation to make a prosocial difference. Academy of Management Review, 32(2), 393-417.

Grayson, D., and Hodges, A. (2017). Corporate social opportunity!: Seven steps to make corporate social responsibility work for your business. London: Routledge. Retrieved from: www.taylorfrancis.com/books/9781351280884

Griffin, J. J., and J. F. Mahon (1997). The corporate social performance and corporate financial performance debate: Twenty-five years of incomparable research. Business \& Society, 36(1), 5-31.

Gugler, P., and J. Y. Shi (2009). Corporate social responsibility for developing country multinational corporations: Lost war in pertaining global competitiveness? Journal of Business Ethics, 87(1), 3-24.

Gurzawska, A., R. Cardone, A. Porcari, E. Mantovani, and P. Brey (2015). Ethics assessment in different types of organizations: Industry, SATORI Deliverable 1.1: Ethical Assessment of R\&I: A Comparative Analysis; Annex 3h:, SATORI Project. Retrieved from: http://satoriproject.eu/media/3.h-Industry.pdf (accessed: 23 December 2017). 


\section{Agata Gurzawska}

Gurzawska, A., M. Mäkinen, and P. Brey (2017). Implementation of Responsible Research and Innovation (RRI) practices in industry: Providing the right incentives. Sustainability, 9(10), 1759.

Halkos, G., and A. Skouloudis (2018). Corporate social responsibility and innovative capacity: Intersection in a macro-level perspective. Journal of Cleaner Production, 182, 291-300.

Hanekamp, G. (2007). Business ethics of innovation. An introduction. In Hanekamp, G. \& Wütscher, F. (Eds.), Business ethics of innovation (pp. 1-6). Springer-Verlag Berlin Heidelberg. Retrieved from: https://link.springer.com/ book/10.1007/978-3-540-72310-3\#about

Hanke, T., and W. Stark (2009). Strategy development: Conceptual framework on corporate social responsibility. Journal of Business Ethics, 85(3), 507.

Hansen, E. G., F. Grosse-Dunker, and R. Reichwald(2009). Sustainability innovation cube - a framework to evaluate sustainability-oriented innovations. International Journal of Innovation Management, 13(04), 683-713.

Hauser, J., G. J. Tellis, and A. Griffin (2006). Research on innovation: A review and agenda for marketing science. Marketing Science, 25(6), 687-717.

Herrera, M. E. B. (2016). Innovation for impact: Business innovation for inclusive growth. Journal of Business Research, 69(5), 1725-1730.

Hesterly, B. and J. Barney (2008). Strategic management and competitive advantage. Essex: Pearson Education Limited. Retrieved from: www.pearson.com/us/highereducation/product/Barney-Strategic-Management-and-Competitive-AdvantageConcepts-2nd-Edition/9780136135203.html

Hockerts, K., M. Morsing, J. Eder-Hansen, P. Krull, A. Midttun, M. Halme, ... and P. Nurmi (2009). CSR-driven innovation: Towards the social purpose business. Center for Corporate Social Responsibility, CBS.

Hull, C. E., and S. Rothenberg (2008). Firm performance: The interactions of corporate social performance with innovation and industry differentiation. Strategic Management Journal, 29(7), 781-789.

Husted, B. W. and D. B. Allen (2000). Is it ethical to use ethics as strategy? Business challenging business ethics: New instruments for coping with diversity. In Sójka, J., \& Wempe, J. (Eds.), International business (pp. 21-31). Netherlands: Springer. Retrieved from: www.springer.com/gp/book/9780792365860

Husted, B. W., and D. B. Allen (2007). Corporate social strategy in multinational enterprises: Antecedents and value creation. Journal of Business Ethics, 74(4), 345-361.

Husted, B. W., and D. B. Allen (2010). Corporate social strategy: Stakeholder engagement and competitive advantage. Cambridge, UK; New York: Cambridge University Press.

Husted, B. W., D. B. Allen, and N. Kock (2015). Value creation through social strategy. Business \& Society, 54(2), 147-186.

ING. (2008). From sustainability to business value finance as a catalyst. Retrieved from: www.ingwb.com/media/2266556/ing-sustainability-study-2018.pdf (accessed: 15 April 2018).

Iñigo, E. A., and L. Albareda (2016). Understanding sustainable innovation as a complex adaptive system: A systemic approach to the firm. Journal of Cleaner Production, 126, 1-20.

Iyer, G., and D. A. Soberman (2016). Social responsibility and product innovation. Marketing Science, 35(5), 727-742. 
Kanter, R. M. (1999). From spare change to real change: The social sector as beta site for business innovation. Harvard Business Review, 77(3), 122-123.

Khaledabadi, H. J., and T. Magnusson (2008). Corporate social responsibility and knowledge management implications in sustainable vehicle innovation and development. Communications of the IBIMA, 6, 8-14.

Kinkel, S., G. Lay, and J. Wengel (2005). Innovation: more than research and development. Growth opportunities on different innovation paths (No. 33e). Bulletins manufacturing innovation survey.

Koistinen K., M. Laukkanen, M. Mikkilä, J, Huiskonen, and L. Linnanen (2018). Sustainable system value creation: Development of preliminary frameworks for a business model change within a systemic transition process. In: Moratis L., Melissen F., \& Idowu S. (Eds.), Sustainable business models. CSR, sustainability, ethics o governance. Cham: Springer. Retrieved from: http://link-springer-com-443. webvpn.fjmu.edu.cn/chapter/10.1007\%2F978-3-319-73503-0_6\#citeas.

Kranzberg, M. (1986). Technology and history: "Kranzberg's laws". Technology and Culture, 27(3), 544-560.

Kurucz, E. C., A., Crane, A. McWilliams, D. Matten, J. Moon, \& D. S. Siegel (2008). The business case for corporate social responsibility. In Crane, A., McWilliams, A., Matten, D., Moon, J., and Siegel, D. S. (Eds.), The Oxford handbook of corporate social responsibility (pp. 83-112). Oxford, UK: Oxford University Press.

Lai, W. H., C. C. Lin, and T. C. Wang (2015). Exploring the interoperability of innovation capability and corporate sustainability. Journal of Business Research, 68(4), 867-871.

Lantos, G. P. (2001). The boundaries of strategic corporate social responsibility. Journal of Consumer Marketing, 18(7), 595-632.

Liedtka, J. (2000). In defense of strategy as design. California Management Review, 42(3), 8-30.

Lindner, R., S. Kuhlmann, S. Randles, B. Bedsted, G. Gorgoni, E. Griessler, ... and N. Mejlgaard (2016). Navigating towards shared responsibility. In Research and Innovation: Approach, Process and Results of the Res-AGorA Project. Retrieved from: http://pure.au.dk/portal/files/98634660/RES_AGorA_ebook.pdf.

Longoni, A., and R. Cagliano (2018). Sustainable innovativeness and the triple bottom line: The role of organizational time perspective. Journal of Business Ethics, 151(4), 1097-1120.

Lubberink, R. J. B., V. Blok, J. A. C., van Ophem, and S. W. F. Omta (2017). A framework for responsible innovation in the business context: Lessons from responsible-, social- and sustainable innovation. In L. Asveld, R. van Dam-Mieras, T. Swierstra, S. Lavrijssen, K. Linse, \& J. van den Hoven (Eds.), Responsible innovation 3: A European agenda? (pp. 181-207). Springer, Cham: Springer. Retrieved from: https://research.wur.nl/en/publications/a-framework-for-responsible-innovationin-the-business-context-le

Lubin, D. A., and D. C. Esty (2010). The sustainability imperative. Harvard Business Review, 88(5), 42-50.

Luo, X., and S. Du (2012). Good companies launch more new products. Harvard Business Review, 90(4), 28.

Luo, X., and S. Du (2015). Exploring the relationship between corporate social responsibility and firm innovation. Marketing Letters, 26(4), 703-714.

Lush Cosmetics. Our environmental policy. Retrieved from: https://uk.lush.com/article/our-environmental-policy (accessed: 15 June 2015). 


\section{Agata Gurzawska}

Lynch, R. (2015). Strategic management. Seventh edition. Harlow, UK: Pearson Education Limited. Retrieved from: www.pearson.com/uk/educators/highereducation-educators/program/Lynch-Strategic-Management-7th-Edition/ PGM1069920.html

MacGregor, S. P., and J. Fontrodona (2008). Exploring the fit between CSR and innovation (no. 759). IESE Business School Working Paper.

Maignan, I., and D. A. Ralston (2002). Corporate social responsibility in Europe and the US: Insights from businesses' self-presentations. Journal of International Business Studies, 33(3), 497-514.

Margolis, J. D., and J. P. Walsh (2003). Misery loves companies: Rethinking social initiatives by business. Administrative Science Quarterly, 48(2), 268-305.

Martinez-Conesa, I., P. Soto-Acosta, and M. Palacios-Manzano (2017). Corporate social responsibility and its effect on innovation and firm performance: An empirical research in SMEs. Journal of Cleaner Production, 142, 2374-2383.

Maxfield, S. (2008). Reconciling corporate citizenship and competitive strategy: Insights from economic theory. Journal of Business Ethics, 80(2), 367-377.

McElhaney, K. (2009). A strategic approach to corporate social responsibility. Leader to Leader, 52(1), 30-36.

McElhaney, K. (2009). Just good business: The strategic guide to aligning corporate responsibility and brand. San Francisco, CA: Berrett-Koehler Publishers. Retrieved from: https://books.google.ht/books?id=uYR0zHbSTbsC\&pg=PR3\&s ource $=$ gbs_selected_pages $\&$ cad $=2 \# \mathrm{v}=$ onepage $\& \mathrm{q} \& \mathrm{f}=\mathrm{false}$

McWilliams, A., and D. Siegel (2000). Corporate social responsibility and financial performance: Correlation or misspecification? Strategic Management Journal, 21(5), 603-609.

McWilliams, A., and D. S. Siegel (2011). Creating and capturing value: Strategic corporate social responsibility, resource-based theory, and sustainable competitive advantage. Journal of Management, 37(5), 1480-1495.

McWilliams, A., D. S. Siegel, and P. M. Wright (2006). Corporate social responsibility: Strategic implications. Journal of Management Studies, 43(1), 1-18.

Midttun, A. (2006). CSR and innovation, compatibility or contradiction? Towards a dynamic reinterpretation of CSR. The Norwegian School of Management, CSR paper, 3 .

Midttun, A. (2009). Strategic CSR innovation - serving societal and individual needs. Retrieved from: https://biopen.bi.no/bi-xmlui/handle/11250/940 93 (accessed 15 May 2018).

Milling, P. M., and J. Stumpfe (2000, August). Product and process innovation: A system dynamics-based analysis of the interdependencies. In 18th International Conference of the System Dynamics Society Sustainability in the Third Millennium, Bergen, Norway.

Mintzberg, H., and A. McHugh (1985). Strategy formation in an adhocracy. Administrative Science Quarterly, 30(2), 160-197. Retrieved from: www.jstor. org/stable/2393104

Mintzberg, H., B. Ahlstrand and J. Lampel (1998). Strategy safari. Prentice Hall, London. Cited in Hanke, T., and Stark, W. (2009). Strategy development: Conceptual framework on corporate social responsibility. Journal of Business Ethics, 85, 507-516. 
Muller, A., L. Välikangas, and P. Merlyn (2005). Metrics for innovation: Guidelines for developing a customized suite of innovation metrics. Strategy \& Leadership, 33(1), 37-45.

Nag, R., D. C. Hambrick, and M. J. Chen (2007). What is strategic management, really? Inductive derivation of a consensus definition of the field. Strategic Management Journal, 28(9), 935-955.

Nidumolu, R., C. K. Prahalad, and M. R. Rangaswami (2009). Why sustainability is now the key driver of innovation. Harvard Business Review, 87(9), 56-64. Retrieved from: https://hbr.org/2009/09/why-sustainability-is-now-the-keydriver-of-innovation (accessed 15 May 2018).

Nordic Innovation Centre (2010). CSR-driven innovation - combining design and business in a profitable and sustainable way. August 2010. Retrieved from: http:// nordicinnovation.org/Global/_Publications/Reports/2010/CSR-DRIVEN\%20 INNOVATION \% 20- \% 20Combining \%20design \%20and $\% 20$ business $\% 20$ in $\% 20$ a $\% 20$ profitable $\% 20$ and $\% 20$ sustainable $\% 20$ way.pdf (accessed: 15 April 2018).

OECD. (2005). Oslo manual. Guidelines for collecting and interpreting innovation data. Retrieved from: www.oecd.org/science/inno/2367614.pdf (Accessed: 15 April 2018).

OECD. (2009). Sustainable manufacturing and eco-innovation. OECD. Retrieved from: www.oecd.org/env/consumption-innovation/42957785.pdf (accessed: 15 April 2018).

Orlitzky, M., F. L. Schmidt, and S. L. Rynes (2003). Corporate social and financial performance: A meta-analysis. Organization Studies, 24(3), 403-441.

Padgett, R. C., and J. I. Galan (2010). The effect of R\&D intensity on corporate social responsibility. Journal of Business Ethics, 93(3), 407-418.

Patala, S., A. Jalkala, J. Keränen, S. Väisänen, V. Tuominen, and R. Soukka (2016). Sustainable value propositions: Framework and implications for technology suppliers. Industrial Marketing Management, 59, 144-156.

Porter, M. E. (1985). The Competitive advantage: Creating and sustaining superior performance. New York: Free Press. Retrieved from: www.hbs.edu/faculty/Pages/ item.aspx? num $=193$

Porter, M. E. and M. R. Kramer (2002). The competitive advantage of corporate philanthropy. Harvard Business Review, 80(12), 56-68.

Porter, M. and M. Kramer (2006). Strategy and society: The link between competitive advantage and corporate social responsibility. Harvard Business Review, 84(12), 78-92.

Powell, T. C. (2001). Competitive advantage: Logical and philosophical considerations. Strategic Management Journal, 22(9), 875-888.

Pyszka, A. (2012). Społecznie odpowiedzialne innowacje-konieczność czy moda? Innowacje $w$ zarzadzaniu i inżynierii produkcji. Edited by R. Knosal, 108-18. Retrieved from: www.ptzp.org.pl/files/konferencje/kzz/artyk_pdf_2012/p011.pdf

Reber, B. (2018). RRI as the inheritor of deliberative democracy and the precautionary principle. Journal of Responsible Innovation, 5(1), 38-64.

Responsible-Industry Project Consortium (2017). Responsible-industry guide for the implementation of Responsible Research and Innovation (RRI) in the industrial context. Retrieved from: www.responsible-industry.eu/dissemination/deliverables (accessed: 15 May 2018). 
Reuters. (2018). China to bar people with bad 'social credit' from planes, trains, March 16, 2018. Retrieved from: www.reuters.com/article/us-china-credit/china-to-barpeople-with-bad-social-credit-from-planes-trains-idUSKCN1GS10S (accessed: 16 May 2018).

Rexhepi, G., S. Kurtishi, and G. Bexheti (2013). Corporate social responsibility (CSR) and innovation - the drivers of business growth?. Procedia-Social and Behavioral Sciences, 75, 532-541.

Ribeiro, B. E., R. D. Smith, and K. Millar (2017). A mobilising concept? Unpacking academic representations of responsible research and innovation. Science and Engineering Ethics, 23(1), 81-103.

Rip, A. (2018). The past and future of RRI. In Futures of science and technology in society. Technikzukünfte, Wissenschaft und Gesellschaft / Futures of Technology, Science and Society. (pp. 115-133). Wiesbaden: Springer VS. Retrieved from: https://link.springer.com/chapter/10.1007/978-3-658-21754-9_7\#citeas

Roman, R. M., S. Hayibor, and B. R. Agle (1999). The relationship between social and financial performance: Repainting a portrait. Business \& Society, 38(1), 109-125.

Rural Spark. Retrieved from: www.ruralspark.com/ (accessed: 15 May 2018).

Sánchez, P. E., and S. Benito-Hernández (2015). CSR policies: Effects on labour productivity in Spanish micro and small manufacturing companies. Journal of Business Ethics, 128(4), 705-724.

Sawhill, J., and D. Williamson (2001). Measuring what matters in nonprofits. McKinsey Quarterly, (2), 98-107. Retrieved from: www.mckinsey.com/industries/ public-and-social-sector/our-insights/measuring-what-matters-in-nonprofits

Sharma, S., and H. Vredenburg. (1998). Proactive corporate environmental strategy and the development of competitively valuable organizational capabilities. Strategic Management Journal, 19(8), 729-753.

Shen, R., Y. Tang, and Y. Zhang (2016). Does firm innovation affect corporate social responsibility? (No. 16-096). Harvard Business School Working Papers. Retrieved from http://hdl.handle.net/1765/99614

Stilgoe, J., R. Owen, and P. Macnaghten (2013). Developing a framework for responsible innovation. Research Policy, 42(9), 1568-1580.

Sutcliffe, H. (2011). A report on responsible research and innovation. MATTER and the European Commission. Retrieved from https://ec.europa.eu/research/sciencesociety/document_library/pdf_06/rri-report-hilary-sutcliffe_en.pdf

Taebi, B., A. Correlje, E. Cuppen, M. Dignum, and U. Pesch (2014). Responsible innovation as an endorsement of public values: The need for interdisciplinary research. Journal of Responsible Innovation, 1(1), 118-124.

Tantalo, C., and R. L. Priem (2016). Value creation through stakeholder synergy. Strategic Management Journal, 37(2), 314-329.

Tesla. Solar Roof. Retrieved from: www.tesla.com/en_EU/solarroof (accessed: 15 May 2018).

Trott, P. (2008). Innovation management and new product development. Pearson Education.

Ueki, Y., C. Jeenanunta, T. Machikita, and M. Tsuji (2016). Does safety-oriented corporate social responsibility promote innovation in the Thai trucking industry? Journal of Business Research, 69(11), 5371-5376. 
UNDP (2018). A new approach to an old problem. Clean technology innovation in response to climate change, 2 March 2018. Retrieved from: www.az.undp. org/content/azerbaijan/en/home/presscenter/pressreleases/2018/03/02/a-newapproach-to-an-old-problem-clean-technology-innovation-in-response-toclimate-change.html (accessed: 15 May 2018).

Von Schomberg, R. (2013). A vision of responsible research and innovation. In Owen, R., Bessant, J., \& Heintz, M. (Eds.), Responsible Innovation: Managing the Responsible Emergence of Science and Innovation in Society, 51-74. https:// doi.org/10.1002/9781118551424.ch3

von Weltzien Høivik, H., and D. Shankar (2011). How can SMEs in a cluster respond to global demands for corporate responsibility? Journal of Business Ethics, 101(2), 175-195.

White, M. A., and G. D. Bruton (2010). The management of technology and innovation: A strategic approach. Cengage Learning.

Whittington, R. (2001). What is strategy and does it matter? Cengage Learning EMEA.

Yin, J., and D. Jamali (2016). Strategic corporate social responsibility of multinational companies subsidiaries in emerging markets: Evidence from China. Long Range Planning, 49(5), 541-558.

Zadek, S. (2000). Doing Good and Doing Well: Making the Business Case for Corporate Citizenship. Conference Board. 